\title{
STUDY OF THE INFLUENCE OF VACUUM-ARC COATING ON THE WEAR-RESISTANCE OF PISTON RINGS
}

\author{
Glushkova D. \\ Kharkiv National Automobile and Highway University
}

\begin{abstract}
The effect of a multilayer vacuum-arc nanostructured Ti-Mo-N coating, its application parameters on the wear resistance of piston rings is studied. The effect of the parameters of vacuumarc deposition on the nanohardness is established.
\end{abstract}

Key words: vacuum-ars settling, nanohardness, wear-resistant, piston rings.

\section{Introduction}

The production of piston rings the main failure of which is wearing of working surfaces takes a considerable place during various parts producing. Therefore large attention is payed to the problems of wear resistance improvement of pairs of friction of piston rings surfaces.

The creation of combination of high hardness with high plasticity is real in a heterogeneous alloy.

The problem of developing a method for increasing the wear resistance of piston rings seems to be a topical issue.

\section{The analysis of publications}

As it is indicated in the work [1], the wear resistance of metal is determined by combination of a structure and series of properties, that is namely high hardness and plasticity in absence of fragility, stability of mechanical properties in the conditions of work for wearing, the high saturation and the uniform distribution of alloying elements.

In the work [2] it is set that the intensity of relaxation processes proceeding at a friction has a substantial effect on wear resistance.

Lately for the improvement of operating characteristics of materials it is widely used the treatment of surfaces with high intensive sources of energy, the interaction of which with materials results in running of processes related to the structure change.
Foremost there is a change of crystal lattice parameter, the dislocation structures are formed, ultra-dispersive phases are appeared.

The result of such processes is the appearance of residual internal stresses in surface layers of material. A series of works [3, 4] deals with methods of determination and study of nature of residual stresses forming in the coatings got at vacuum-arc precipitation.

The objective of this work is a research of the multi-layered nanostructural coating applied on the piston rings surface for their wear resistance improvement.

Material and procedure of research

The material on the multi-layered coating was applied by means of vacuum-arc method was the grey cast-iron widely used in different branches of engineering. As it is generally known, grey cast-iron has good casting and antifriction characteristics, it is insensible to the defects of surface, suppresses well the vibrations.

Chemical composition of grey cast-iron is given on Table 1.

Studies undertaken last years testify that multicomponent and multi-layered coatings excel the monolayer coatings in properties [5].

Multi-layered two-phase nanostructural coatings TiN-MoN were precipitated in the vacuumarc plant "Булат-6".

The circuit of plant for getting the multilayered samples is shown on Fig. 1.

Table 1 - Chemical composition of grey cast-iron

\begin{tabular}{|l|l|l|l|l|l|l|}
\hline \multicolumn{7}{|c|}{ Composition of elements, \% } \\
\hline $\mathrm{C}$ & $\mathrm{Si}$ & $\mathrm{Mn}$ & $\mathrm{Ni}$ & $\mathrm{S}$ & $\mathrm{P}$ & $\mathrm{Fe}$ \\
\hline 3,49 & 2,49 & 0,56 & 0,08 & 0,06 & 0,11 & rest \\
\hline
\end{tabular}




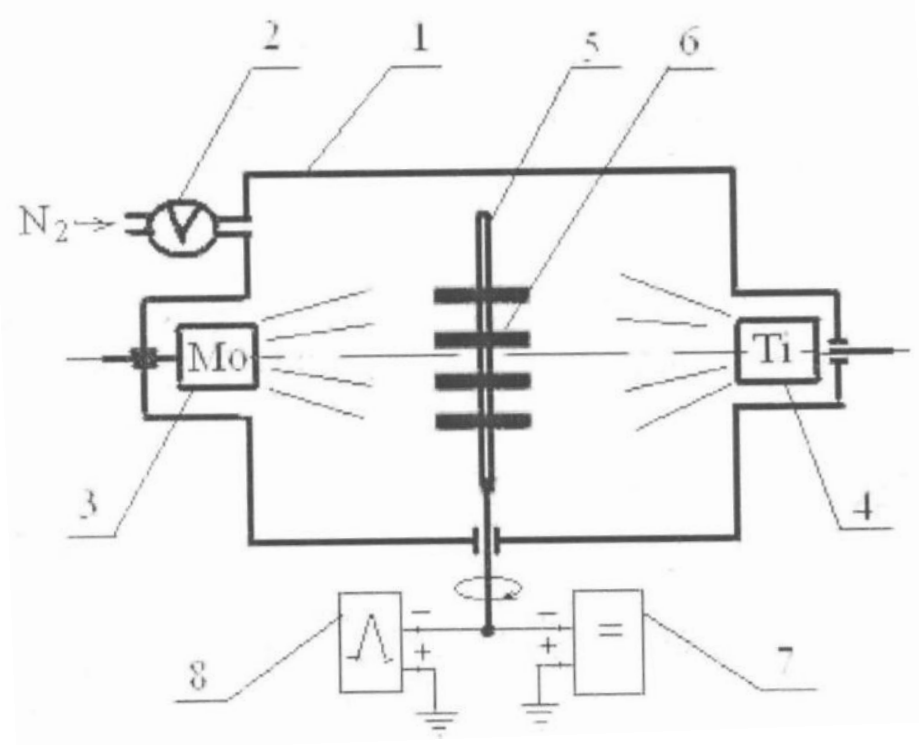

Fig. 1. Circuit of the plant for applying multi-layered coatings: 1 - vacuum chamber; 2 - system of automatic maintenance of nitrogen pressure; 3 - vaporizer of molybdenum; 4 - vaporizer of titan; 5 - backholder; 6 - substrate; 7 - source of direct voltage; 8 - generator of impulse voltage

The vacuum chamber 1 is provided with the system of automatic maintenance of nitrogen pressure 2 and with two vaporizers, one of which 3 contains the molybdenum of brand МЧВП as the evaporated material, and the other 4 is titan of brand BT1-0. On a barturner of the chamber it is installed the backholder 5 like a tube on which the rollers 6 are placed. The plant is provided with a source of direct voltage 7 and also the generator of impulse voltage 8 with controlled amplitude of impulses.

The procedure of multi-layered diphasic coatings cooling included the following operations. The vacuum chamber was pumped out to pressure $1,33-10^{-3} \mathrm{~Pa}$.

Then they gave a negative potential $1,3 \mathrm{~kW}$ to a barturner with backholder, turned on the barturner 5 for continuous rotation and by turns impulsively turned on the vaporizers 3 and 4, thus producing the cleaning of surface of rollers 6. General time of cleaning was 10 minutes.

Further they turned on simultaneously both the vaporizers and precipitated Ti-Mo, after that they gave nitrogen to the chamber and precipitated nitride of molybdenum, and from the opposite side - nitride of titan to continuously rotating rollers. Such parameters as current of arc $I$, direct voltage on the back, impulse voltage on the back, pressure of nitrogen, amount of layers of spraying were varied, the time of spraying was 2 hours.

Nanoindentation was conducted by means of a pyramid of Berkovich at loading $0,5 \mathrm{H}$ with loading and unloading executed automatically.
Metallography researches were conducted by means of electronic microscope, study of the structural state of coverages was performed on a scanning microscope.

The quantity of residual stresses in nearsurface layers was determined on the plant ДРОН-2 by means of procedure of multiplied inclined shootings in radiation of copper anode with graphite monochromator.

The tests for wear resistance were performed on the plant СМЦ-2.

\section{Results of researches and their discussion}

The conducted tests of nanohardness gave the opportunity to get information about the character of distribution of nanohardness in the surface skims of coating Ti-Mo-N.

On Fig. 2 it is shown the chart of distribution of nanohardness to the depth of $220 \mathrm{~nm}$, due to which it is clear that the maximal values of nanohardness take place at the very surface, as far as moving away from surface the nanohardness decreases having a minimum value on the depth of $40 \mathrm{~nm}$, and then it increases a little. At that the loading was reaching the maximal value at intrusion into the surface for depth of $200 \mathrm{~nm}$ (Fig. 3).

As for the Young's modulus it also has the maximum value on depth of $10 \mathrm{~nm}$ (Fig. 4).

Received dependences testify that nanohardness and given Young's modulus are of maximal in surface layers. This conformity to natural law coincides with the results stated in works $[6,7]$. 

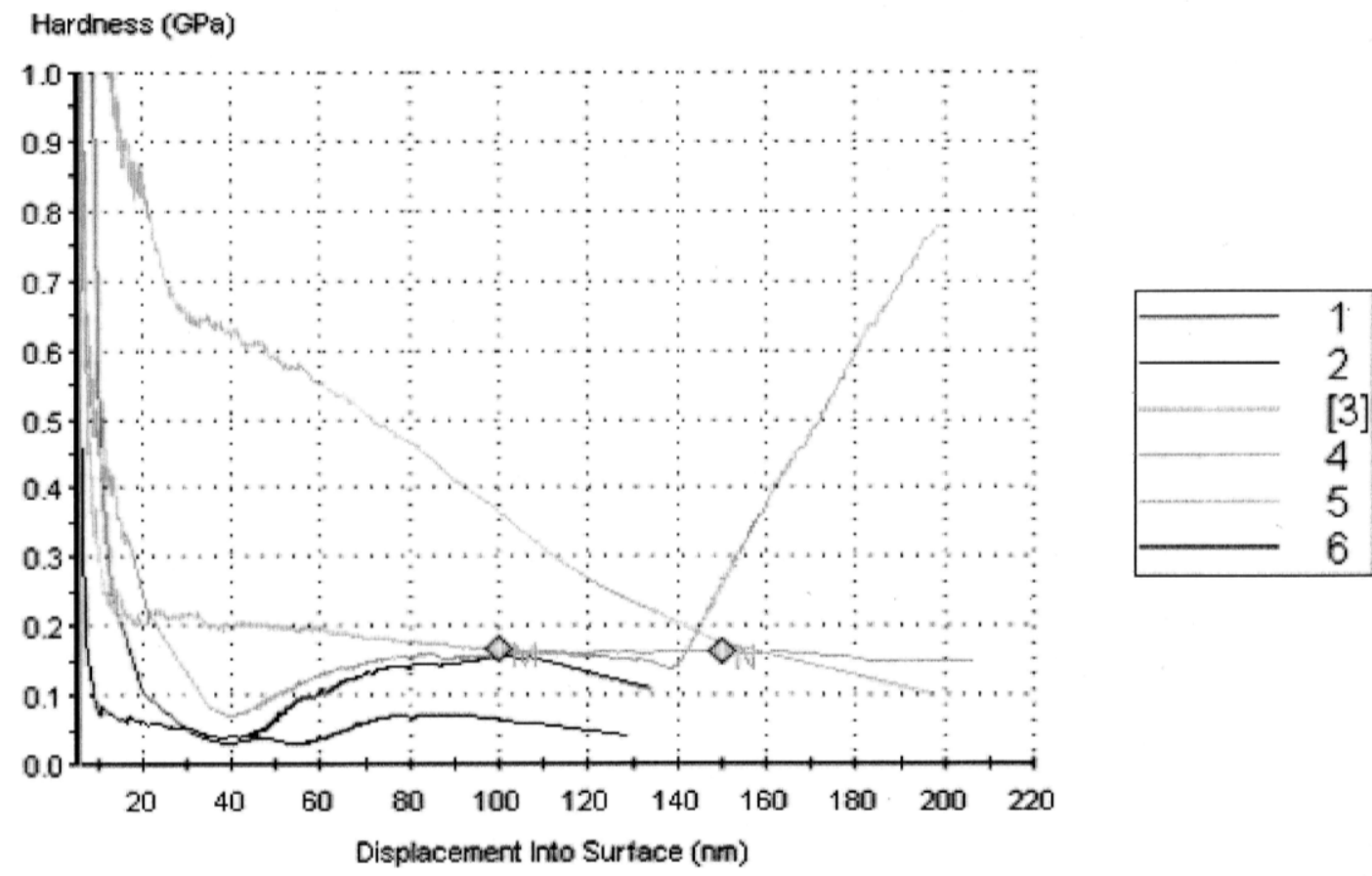

Fig. 2. Chart of nanohardness distribution
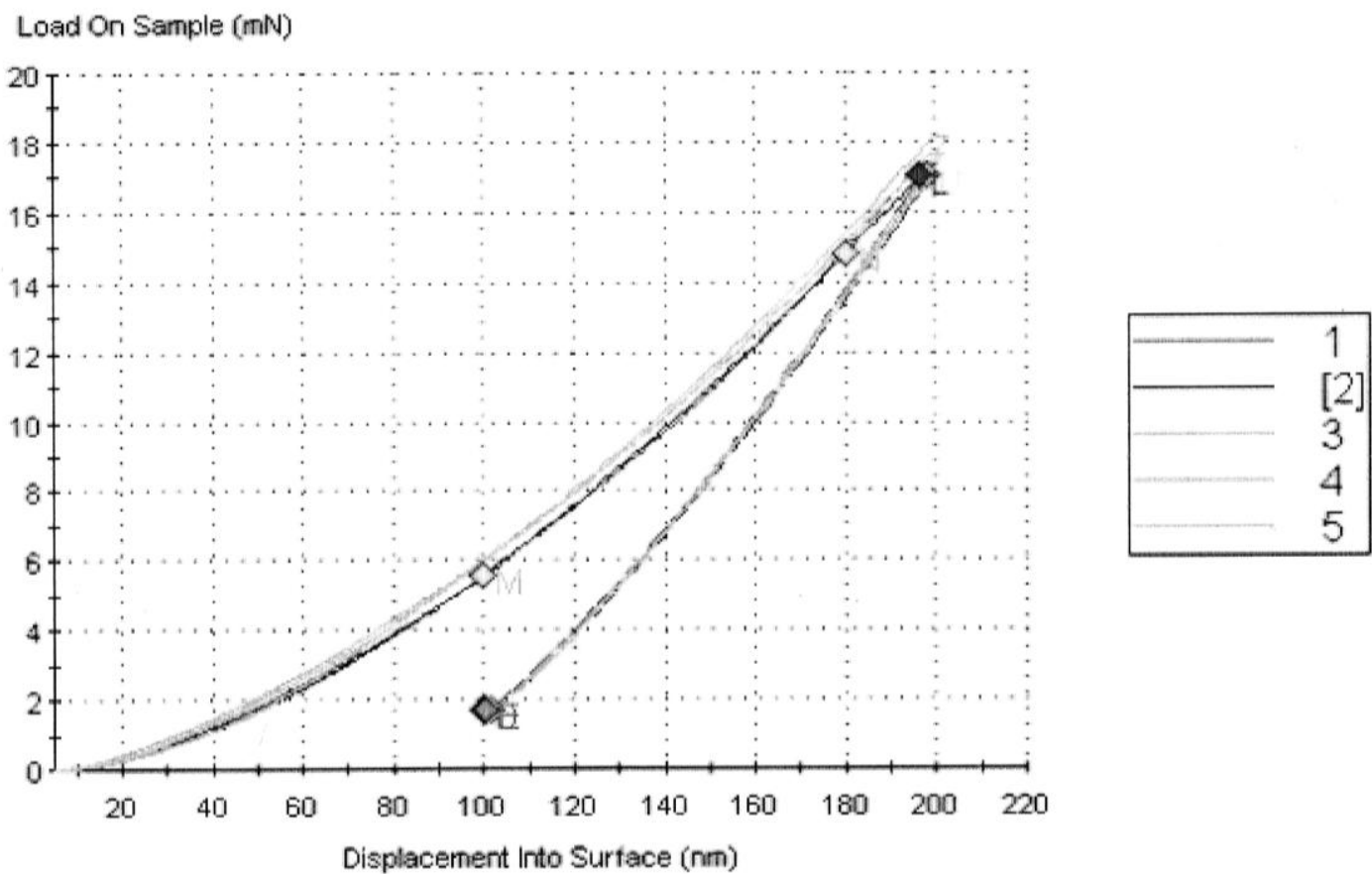

Fig. 3. Chart of loading distribution

The analysis of deflected mode has demonstrated that the highest value of compression corresponds to the depth $10 \mathrm{~nm}$. Such result was received in case of applying coating TiN-MoN at arc $I=100-170 \mathrm{~A}$, direct voltage on the substrate $40 \mathrm{~V}$, impulse voltage on the back $2000 \mathrm{~V}$, nitrogen pressure $1 \cdot 10^{-3} \mathrm{~mm}$ of mercury column, continuous rotation of 2700 layers. Deformation of compression constitutes - 2,2\% on such depth.
The obtained data match the chart of nanohardness given on Fig. 2, which indicates that the maximal value of nanohardness takes place on the depth $\sim 10 \mathrm{~nm}$.

The texture observed at the study on the electronic microscope (Fig. 5) is of important factor in forming the residual stresses in coating. The reason of residual stresses is an impact of ionic bombardment. 


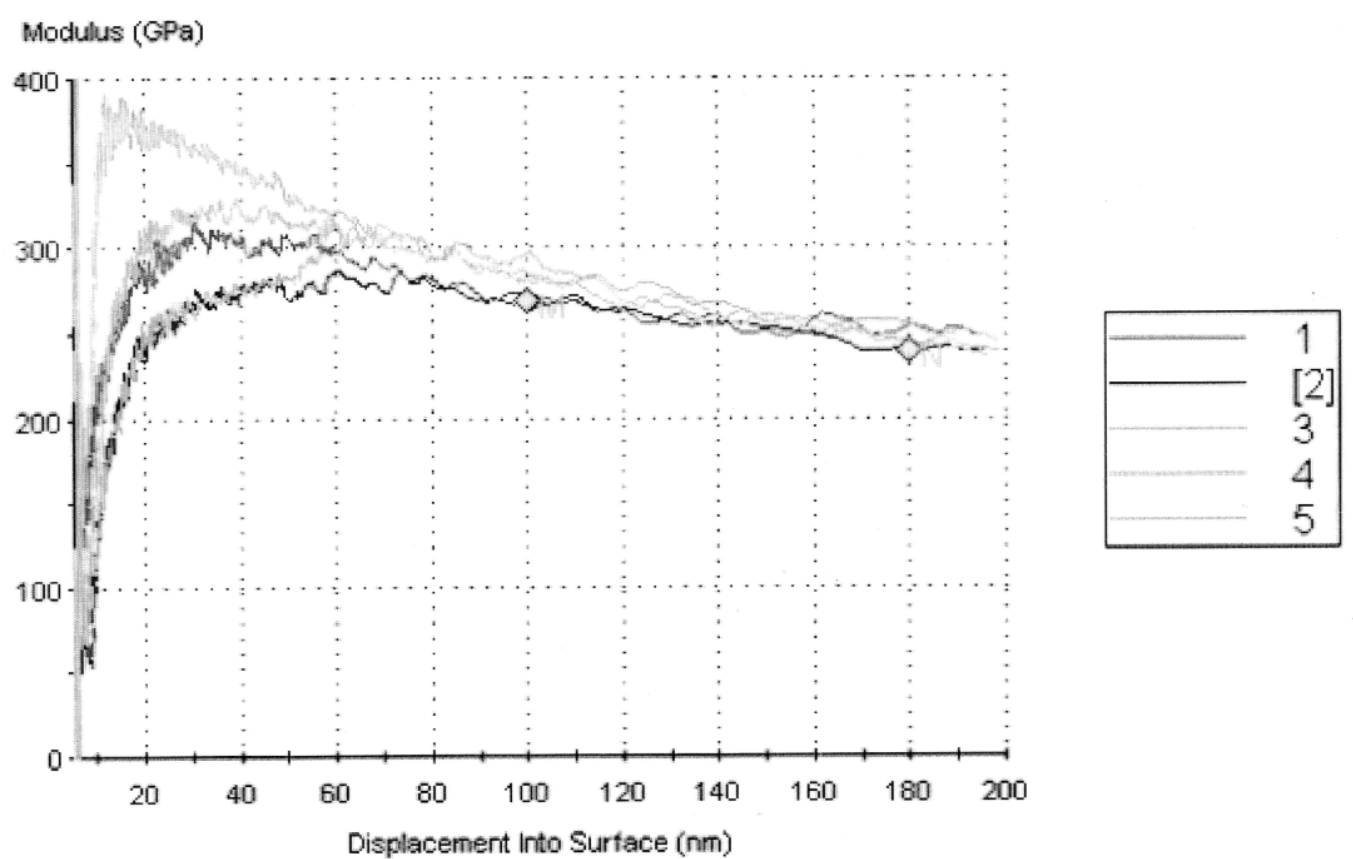

Fig. 4. Chart of distribution of module Yung



Fig. 5. Electronic photography of surface layer structure x10000

Research of the structural state of coatings showed that at the layer thickness about $2 \mathrm{~nm}$ there is no interface border and that's why a spectrum is revealed on diffractive spectrums that is typical for monophasic state and material is hardened not much. The hardness increases at occurrence of the second phase. Thus, as follows from the results of studying the coatings by means of the scanning microscope, the cells on the coating surface are expressed in relief, that can be explained by means of the processes of their dispersion by the ions of molybdenum and titan during precipitation.

In case of studying the layers of thickness $10 \mathrm{~nm}$ it is observed the forming of two-phase structural state. The interfaces occupy a large specific volume, that is accompanied by the increasing of compressive stresses. It must result in hardening, The study of microfractograms of multi-layered coating has shown that formed chips have a regular enough shape specified for destruction of metal under the effect of compression.

The research of layers of thickness $20 \mathrm{~nm}$ showed more washed out interface border that leads to the reduction of specific deposit of borders.

On Fig. 6-9 the histograms of nanohardness are presented at the vacuum-arc precipitation of multilayered nanostructural coatings TiN-MoN, having been got at different parameters, allowing to set the influence of amount of layers of continuous rotation, pressure of nitrogen, impulse voltage on the back on the value of nanohardness. 


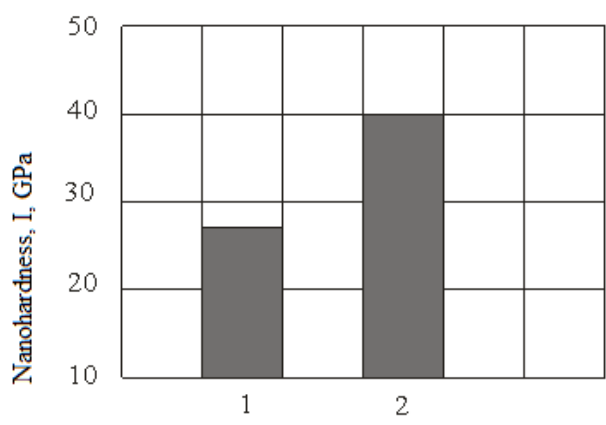

Fig. 6. Histograms of nanohardness at the vacuum-arc precipitation of multi-layered nanostructural coatings $\mathrm{TiN}-\mathrm{Mo}_{2} \mathrm{~N}$ at current of arc $I=100-170 \mathrm{~A}$, direct voltage on the back $40 \mathrm{~V}$, impulse voltage on the back $2000 \mathrm{~V}$, pressure of nitrogen $1 \cdot 10^{-3} \mathrm{~mm}$ of mercury column. Time of spraying is 2 hours. 1 - continuous rotation of 1800 layers; 2 - continuous rotation of 2700 layers

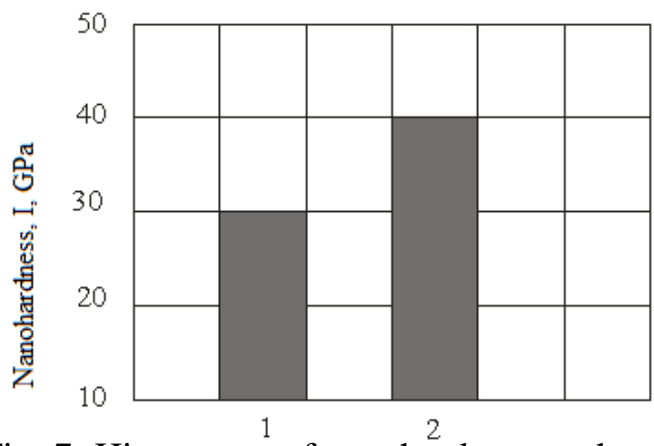

Fig. 7. Histograms of nanohardness at the vacuum-arc precipitation of multi-layered nanostructural coatings TiN-MoN at the current of arc $I=100-160$ A, direct voltage on the back $230 \mathrm{~V}$, without impulses, continuous rotation of 1800 layers. Time of spraying is 2 hours. 1 - Nitrogen pressure at $3 \cdot 10^{-3} \mathrm{~mm}$ of mercury column; 2 - nitrogen pressure at $5 \cdot 10^{-4} \mathrm{~mm}$ of mercury column



Fig. 8. Histograms of nanohardness at the vacuum-arc precipitation of multi-layered nanostructural coatings TiN-MoN at the current of arc $I=105-100 \mathrm{~A}$, direct voltage on the back $230 \mathrm{~V}$, without impulses, continuous rotation of 1800 layers. Time of spraying is 2 hours. 1 - Nitrogen pressure at $3 \cdot 10^{-3}$ $\mathrm{mm}$ of mercury column; 2 - nitrogen pressure at $5 \cdot 10^{-4} \mathrm{~mm}$ of mercury column

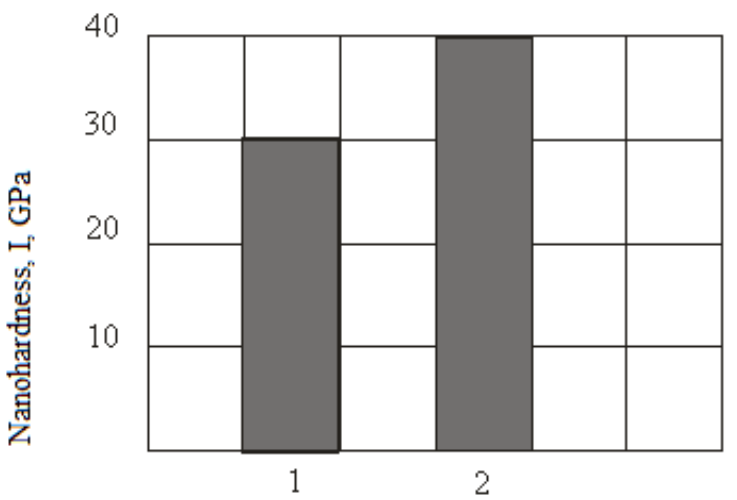

Fig. 9. Histograms of nanohardness at the vacuum-arc precipitation of multi-layered nanostructural coatings TiN-MoN at current of arc $I=100-170 \mathrm{~A}$, direct voltage on the back $40 \mathrm{~V}$, nitrogen pressure at $5 \cdot 10^{-4} \mathrm{~mm}$ of mercury column. Time of spraying is 2 hours. 1 - without impulses; 2 - impulse voltage on the back $2000 \mathrm{~V}$

Spraying the duplex coating on grey cast-iron and processers accompanying it have led to the substantial increase of wearproofness (Fig. 10).

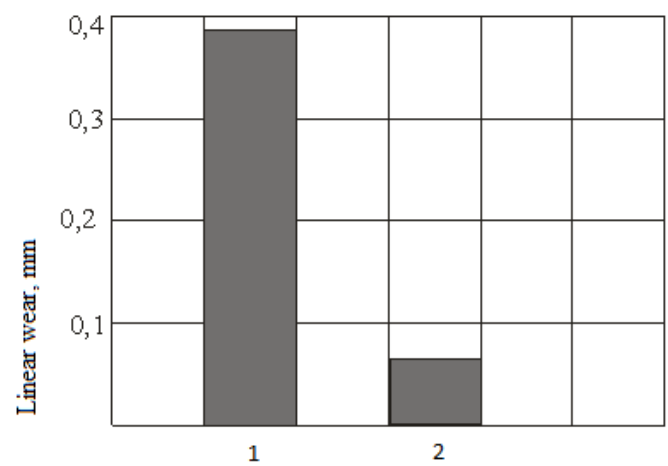

Fig. 10. Histograms of linear wear for 5 hours at loading $1000 \mathrm{Kg} / \mathrm{cm}^{2}: 1$ - grey cast-iron without coating; 2 - cast iron after precipitation of multi-layers coatings TiN-MoN

\section{Conclusions}

1. Spraying the multi-layered coatings TiN-MoN on grey cast-iron creates compressive stresses on the surface.

2. At the very surface it is observed the maximal values of nanohardness and modul's Yung at spraying the coating Ti-Mo-N.

3. Linear wear of cast-iron sprayed with coating Ti-Mo-N decreases in 8 times.

4. Nanohardness increases on proximately $40 \%$ in the same conditions of spraying at continuous rotation with the increasing of amount of layers from 1800 to 2700 . 
5. Nanohardness increases on proximately on $25 \%$ at increasing of vacuum for all identical parameters of spraying the coating.

6. The vacuum-arc precipitation performed at impulse voltage on a base, equal to $2000 \mathrm{~V}$ provides the increasing of nanohardness on $30 \%$ as compare to without impulse one at all other equal conditions for conducting the experiment.

\section{Literature}

1. Matsevityi U.M. On the way of steady development of scientific researches // Problems of engineering industry. 2002. Vol. 5. № 2. P. 5-18.

2. Grinkevich K.E. Some positions of structure dynamic conception of tribosystem and their practical realization // Friction and wear. 2003. № 3. P. 344-350.

3. Birger A.I. Residual stresses. Moscow: State Publishing House of Engineering, 1993. 232 p.

4. Kovalenko A.D. Thermoelasticity. Kyiv: Higher school, 1995. $216 \mathrm{p}$.

5. Experience of exploitation and increasing the efficiency of the use of the plants "Bulat" / Padalka V.G. and others of NAS of Ukraine. National Scientific Center of "Kharkov PhysicMechanical Institute", 1961. Moscow: CSIIatominform, $1986.56 \mathrm{p}$.

6. Vacuum-arc device and coating / Andreev A.A., Sablev L.P, Shulaev V.M., Grigoriev S.N. // Library of NSC Kharkov Physic-Mechanical Institute. Kharkiv, 2005. 238 p.
7. Suzuki M. Tribological performance of a sputtered $\mathrm{Mo}_{2}$ \& film in air $\mathrm{N}_{2}, \mathrm{O}_{2}, \mathrm{H}_{2} \mathrm{O}$ environments at pressures from $10^{-5} \mathrm{~Pa}$ to $10^{5} \mathrm{~Pa} / /$ Journal of society of Tribologists and Lubrication Engineers, 2001. Vol. 57. № 1. P. 23-29.

Hlushkova D., Doct. Sc., Chef of Department of Technology of Metals and Materials Science, tel: (057) 707-37-29, diana@khadi.kharkov.ua,

Kharkiv National Automobile and Highway University, 25, Yaroslava Mudrogo str., Kharkiv, 61002, Ukraine.

\section{Дослідження впливу вакуумно-дугового по-} криття на зносостійкість поршневих кілець

Анотація. Досліджено вплив багатошарового вакуумно-дугового наноструктурного покриття Ti-Mo-N, параметрів його нанесення на зносостійкість пориневих колець. Установлено вилив параметрів вакуумно-дугового осаджування на нанотвердість.

Ключові слова: покриття, нанотвердість, зносостійкість, пориневі кільия.

Глушкова Діана Борисівна, д.т.н., проф., завідувач кафедри технології металів та матеріалознавства, тел. 057-707-37-29, e-mail: diana.borisovna@gmail.com

Харківський національний автомобільнодорожній університет, вул. Ярослава Мудрого, 25 , м. Харків, 61002, Україна. 